\title{
Indonesian discourse particles in conversations and written text
}

\author{
DAVID-M. KARÀJ
}

\begin{abstract}
The aim of the present article is to analyse the four most frequent Colloquial Indonesian discourse particles (lho, kok, sih, and dong) and to compare their occurrences in both spontaneous spoken conversations and written texts (articles from an online youth magazine). The latter method is uncommon, as most studies on Indonesian discourse particles focus exclusively on spoken data. My motivation for choosing the term "discourse particles" (instead of, for example, pragmatic particles) is explained and a new language-specific definition of the phenomenon is proposed. First, the particles' meanings as given in various dictionaries are presented, followed by examples from spontaneous conversations. Next, examples from written texts are given, followed by an analysis of possible differences and similarities in meaning. Finally, the possible meanings of the particles are exemplified through sample sentences using semantic explication. By conclusion, I attempt to answer the question of whether the discourse particles in Colloquial Indonesian can be considered as a separate word class.
\end{abstract}

KEYWORDS

Discourse particles; Colloquial Indonesian; spoken language.

\section{INTRODUCTION}

The aim of the present article is an investigation into the nature of discourse particles in contemporary Indonesian, and a comparison between their usage in spoken conversations and written texts (articles in an online magazine). Indonesian discourse particles are a linguistic phenomenon which has been paid increased interest of scholars in recent years, especially in the context

\footnotetext{
DAVID-M. KARÀJ is a PhD candidate in Linguistics at the University of Pavia. His main research interests revolve around the Malay World, its culture, and foremost - its languages, particularly Malay syntax on various stages of language development. He is currently working on a project regarding valency-changing operations in Malay and their synchronic development. David-M. Karàj can be reached at: davidmkaraj@gmail.com.
} 
of so-called "Jakartan Indonesian" (see inter alia James Neil Sneddon 2006). ${ }^{1}$ However, to the best of my knowledge, no attempt has been made to take a closer look at the particles occurring in writing. It has been observed that elements from the colloquial register enter other domains, in which they would have not normally been present before (for example, in advertisements, announcements, and literature) and appear frequently in the media (television, Internet, et cetera). Therefore, I had assumed that the discourse particles, which were previously considered to be solely used in the spoken language, would also be found in writing. In this article I present four common Colloquial Indonesian (hereafter: CI) discourse particles: sih, kok, dong, lho as they appear in various dictionaries. Next, I present examples from colloquial conversations discussing the particles' meanings and cross-examine them using existing research on the topic, and finally I analyse the material found in articles from a popular magazine in order to see whether there are any variations in the meaning of the particles occurring in writing.

\subsection{DisCOURSE PARTICLES - A PROBLEM OF DEFINITION}

One of the first obstacles in the research of discourse particles is deciding how to name these elements and, secondly, agreeing upon a working definition of this phenomenon. In the existing literature we encounter a wide array of terms such as "discourse markers/particles", "pragmatic particles/markers", "emotive particles", and others. In this study I have decided to use the term "discourse particles". I have chosen the term "particles" rather than "markers" as this study discusses the small units of speech rather than phrases which could also serve as discourse markers. I have also decided to use the term "discourse" rather than "pragmatic" or "emotive", as I would like to stress their discursive function in its entirety rather than focusing on singular aspects of their meaning. In the definition of discourse particles, there seems to be no academic consensus (see Andreas Jucker and Yael Ziv 1998; Thanh Nyan 2016: 2 ), so that I have decided to formulate one definition based on the existing ones, which could specifically serve this study. Most reviewed definitions were not language-specific (Mira Ariel 1998: 223; Yael Maschler 1998: 31; Manfred Stede and Birte Schmitz 2000: 126). Only one of them was specific to Indonesian (Sneddon 2006: 117). Based on the material in this study, I have created a concise definition which, in my opinion, encapsulates the essence of discourse particles in CI:

Discourse particles are syntactically optional, short speech elements, usually without fixed meaning, providing a comment on what has just been said or done. Their meaning varies depending on the context and position in an utterance.

${ }^{1}$ In the present work I do not refer to the language analysed as "Jakartan Indonesian", as my research has shown that the usage of certain elements, including discourse particles, is not confined to the Jakartan variety of Indonesian and is spreading to other parts of the country, such as Surakarta where I collected my data. Therefore, the present article uses the term Colloquial Indonesian (CI). 
I find it important to stress the following aspects: (1) optionality; (2) the lack of fixed meaning; (3) their pragmatic function in the ongoing discourse (being a kind of a comment on what just happened or has been said by the interlocutor); and (4) the changes in a particle's meaning depending on its position. The above definition serves as the starting-point for the considerations undertaken in this study.

\section{Methods}

The data for this research were gathered during my stay in Surakarta, Central Java, Indonesia, from August 2017 to May 2018. The first part of the investigation was conducted on the basis of spoken conversations among Indonesians (mostly Javanese for whom Indonesian is their second language). The second part is a corpus analysis of the articles of one of the popular online magazines addressed to a young audience: Brilio.net. ${ }^{2}$ I have analysed the frequency of four particles - lho, kok, sih, and dong - their positions in a clause, common collocations, and their possible meanings. Moreover, the study of the particles' meaning would not be complete without taking into consideration dictionary entries, which constitute more or less accurate attempts to illustrate the functions of the particles. Interestingly, few discrepancies were found between dictionary definitions and what linguistic research has shown. For the analysis I have chosen four dictionaries. Two are monolingual: Kamus Besar Bahasa Indonesia (KBBI, The Great Dictionary of Indonesian Language, Badan Bahasa 2016) and the Malaysian Kamus Dewan (KD, The Dictionary of Language Bureau, Hajah Noresah bt. Baharom 2007), which includes Indonesian particles among its entries. The other two are bilingual: Kamus Indonesia-Inggris (KII, Indonesian-English Dictionary, John M. Echols and Hasan Shadily 2014), and Kamus Lengkap (KL, Complete Dictionary, Suwojo Wojowasito and Tito W. Wasito 2007). The examples taken from the articles are presented in the way they were found on the website; I have kept the original spelling of the words which did not meet the commonly accepted conventions in terms of capitalization, punctuation, orthography, and other deviations from Standard Indonesian. I shall begin with a discussion of the particles' meanings according to their dictionary definitions plus examples from spoken language. This is followed by an analysis of the particles occurring in written texts and by a discussion of their meanings through semantic explication, that is, by assigning to each particle a set of explanatory paraphrases which will help us understand their meanings.

\section{STUDY OF THE PARTICLES}

This article focuses on four common CI discourse particles: lho, kok, sih, and dong. Exploring their meanings is especially interesting in the context of the relationship between Indonesian (and closely related Malay) and Javanese. Contemporary Indonesian and Malay (mostly Malaysian Malay)

${ }^{2}$ See http://www.brilio.net/. 
are two languages which, in their standard varieties, show a great number of similarities both in grammar and vocabulary, and remain largely mutually intelligible. However, their informal registers differ significantly, including in their discourse particles (see Malcolm Warren Mintz 1994: 402; Tom G. Hoogervorst 2018). Only a few of them occur in both languages (for example lah, nih, tuh, kan, ya) with differences in their frequency and usage. Some of the particles studied in this article are also present in Javanese (lho and kok) and are probably borrowed from that language. It is important to note that, in Javanese, the discourse particles occur in both registers of the language low (ngoko) and high (krama), while in Indonesian they tend to remain a part of the informal register (with occasional occurrences in the formal language).

For each particle, the search engine returned on average fifty web addresses - forty-eight for sih, twenty-seven for kok, forty-two for dong, forty-nine for lho, and twenty-three for loh (that is seventy-two in all for what is described here as particle $l h o$ ). It is important to note that in many instances the text occurring in the headline of an article is repeated within the body of the text, sometimes with a slight modification. Therefore, the figures presented in Table 1 , even though extracted directly from the search engine, should be treated as close estimates.

\begin{tabular}{|l|l|l|}
\hline \multicolumn{2}{|c|}{ Particles } & Results \\
\hline \multirow{2}{*}{ lho } & tho-total number & 278 \\
\cline { 3 - 3 } loh & & 123 \\
\hline sih & 185 \\
\hline kok & 150 \\
\hline dong & 112 \\
\hline
\end{tabular}

Table 1. Frequency of the particles.

\subsection{EXISTING STUDIES}

As mentioned previously, $\mathrm{CI}$ is the subject of an increasing number of publications. Some works dedicated to the language spoken by Jakartans include Muhadjir (1981), Henri Chambert-Loir (1983), Fay Wouk (1989), C.D. Grijns (1991), Sneddon (2006), while others attempt descriptions of CI in general (J.S. Badudu et al. 1984; Robert Englebretson 2003; Michael C. Ewing 2005). A significant part of such publications focuses on the sociolinguistic aspects of non-standard language (Abdul Chaer dan Augustina Leonie 2004; R. Kunjana Rahardi 2001) or the language of young people (Siti Perdi Rahayu 1999; Umar Solikhan 2006). Among these publications, few papers pay attention to individual particles (Wouk 1998, 2001; Dientha Yuniar 2013; Y. Miyake 2015), while a more complete overview of CI particles can be found in Sneddon (2006: 117-130). It is important to note that several Indonesian language textbooks also introduce the learner to discourse particles (Yohanni Johns 1993; Ljudmila Demidjuk et al. 2013). 


\section{2 dong}

According to both KBBI and KD, the particle dong serves as a "sweetener" (pemanis) or "softener" (pelembut) of the speaker's intentions. However, KII defines the particle as "a mild way of saying something" and underlines that it is used at the end of a sentence. The entry in KL is strikingly similar to the description found in a textbook written by Johns (1993: 33). According to both Johns (1993: 33) and Sneddon (2006: 118), using the particle dong implies that the listener is aware of the speaker's intentions, or knows what the speaker is talking about. Let us consider Example (1):

\section{(1) A: Autumn in UNS season ini masih ada toh? \\ this still there.is PART?}

'So, there's still an "Autumn at UNS season"3 going on there?'

B: Masih dong, edisi terbaru.

still PART edition newest

'Sure there is, the newest edition.'

In (1), $\mathrm{A}$ is asking a question referring to a set of photographs taken by B on a university campus. In this case, the usage of the particle dong in B's reply refers to the facts known by A. The question is rhetorical, as A has seen the photographs and knows that the "Autumn at UNS season" is not yet over.

Another example (2) also refers to a situation known to both interlocutors. $\mathrm{A}$ is aware that B is running late but urges them with a rhetorical question; "Just a few more minutes (you know)" is only a working translation here, as the precise meaning is along the lines of "I know it's taking longer than usual but I still need some more time".

(2) A: Masih lama?

still long

'Is it going to take much longer?'

B: Nggak, sebentar lagi dong.

no a.moment again PART

'No, just few more minutes (just bear with me).'

The particle dong also commonly occurs in imperatives as in (3).

(3) Program-nya seperti apa? Jelasin dong!

programme like what explain PART

'What is this programme about? Explain, please!'

${ }^{3}$ Name of a university in Surakarta, Central Java, Indonesia - Universitas Sebelas Maret. 
As can also be seen from the above example, as a mild imperative the particle dong seems to give a sense of encouragement. The speaker is probably aware that the information about the programme is going to be followed by a more detailed description, but feels the need to nudge their interlocutor to supply that further information.

Based on the examples above, we can conclude that the dictionary definitions of the particle dong are incomplete. The monolingual dictionaries (KBBI and KD) as well as the KL gloss the particle as a softener only, while KII stresses another aspect, that the addressee already knows what the speaker is trying to communicate, which indeed does appear to be the essence of the particle. None of the dictionary entries point out the emphatic character of the particle, while neither Sneddon nor Johns seem to see dong as a softening particle and stress only its emphatic character. As observed by Miyake (2015), dong might be used as a softener when flirting, when it is usually accompanied by vowel lengthening. Based on the context in which the conversations studied in this paper occurred - informal conversations among peers - it is difficult to discern whether the interlocutors had any reason to strive to be overly polite or to make their requests any milder. An argument in support of this finding is the fact that the particle dong, as has been shown in this research, always refers to a reality known by both participants in the discourse. Therefore, the message carried by the particle seems to be close to "do what you were supposed to do".

In the texts of the articles analysed, the particle dong occurs in final position (4) with only a few exceptions. One occurrence of the particle in a question has been observed (6). In all the instances, the particle conveys a similar meaning to that described above, implying that the reader already knows that the statement they are presented with is true. In (4) I have put the entire phrase in bold, as the meaning of the particle could not be rendered with a single word (see Section 3.6, Phrases 6, 8, and 12).

(4) 10 fashion unik 'Kids Jaman Now', gaya-nya ngejazz banget dong! 10 fashion unique New Generation Kids style jazzy very PART ' 10 unique fashion styles for the up-and-coming generation of kids, look how cool they are!'

In (5), for instance, dong refers to what can be seen in the photographs accompanying the article. The title seems to imply "it's cool, don't you agree?", assuming that the reader would agree with the view expressed. 
(5) Buat kamu yang juga ngikutin serial atau film dari negara Seribu for 2SG which also follow series or movie from country one.thousand Pagoda tersebut pasti tahu dong kalau aktor-aktor di sana ganteng-nya pagoda mentioned sure know PART if actors in.there handsome nggak ketulungan.

no help

'As someone who also watches movies or series from the country of a thousand pagodas, for sure you know that their actors are so impossibly handsome.'

Example (5) is one of the instances in which the particle is not used in the final position. However, this usage does not change its meaning and, again, could be rendered as "for sure" or "of course you know".

As mentioned before, only one instance of particle dong in a question has been noted among the collected data (6). We can see that the function of the particle remains the same as described above. Using it in a question seems to add even more emphasis to the already emphatic character of the particle dong.

(6) Kalau semua makanan memicu kanker, lalu sebaiknya kamu makan apa if all food cause cancer then better 2SG eat what dong? PART

'If all food causes cancer, then what on earth are you supposed to eat?'

\section{$3.3 \operatorname{sih}$}

The dictionary definitions generally depict the particle sih as an emphasizer and/or softener. On the other hand, both Johns (1993: 37-38) and Miyake (2015: 2-5) agree on a sense of irony or sarcasm conveyed by sih, as well as a sense of surprise or puzzlement expressed by the speaker. Sneddon (2006: 126) gives a very generic definition of what the meaning of sih could be: "a softener or 'smoother', contributing to the smooth flow of the conversation". Similarly, KII defines sih as a softener, while the entries in other dictionaries define this particle as an emphasizer. Both KBBI and KD present 'really' or 'sure' as appropriate glosses. The entries from bilingual dictionaries appear to be less clear. KII, however, illustrates sih with several examples, which make it easier to grasp its possible functions. KL, on the other hand, suggests two English equivalents - 'yet' and 'though' - without additional comments or examples. As will be shown here, 'though' can very often serve as an appropriate equivalent for sih.

The analysed data show that sih is very often used to mark rhetorical questions with a mild sense of irony, see (7).

(7) Kamu sayang dia, nggak sih?

2SG love 3SG no PART

'You love her or not?' 
Miyake (2015: 3) argues that sih might show the lack of eagerness of the speaker, coupled with the aforementioned sense of mild irony. In (8) sih could be understood as "yes, that's also true but there's nothing you can do about it".

(8) A: Bukan hanyaitu, sering ada orang yang tidak mengerti not only that often there.is people which not understand istilah-nya. terminology

'That's not the only problem, there are many people who don't understand what it means.'

B: Iya juga sih, aku sering gitu. yes also PART 1SG often this.way

'Yes, true, I'm often like that myself.'

The particle sih has also been found to play an important role when the speaker is hesitating or unsure about whether they would be able to describe the reality accurately. Often the particle was used when the speaker forgot certain information and was asking again for confirmation, see (9).

(9) Kos-nya dimana sih?

boarding.house in where PART

'Where was your boarding house, again?

What is important to note here is that sih also forms idiomatic expressions with question words, such as masa sih? ('how come?'; see Miyake 2015: 5), apa sih? ('what on earth is that?'), bagaimana/gimana sih? ('how on earth?'), kenapa sih? ('why the heck?'), as well as question tag nggak sih? ('right?', 'isn't it?'), and one construction used when contrasting or comparing two ideas (see Johns 1993: 28; Miyake 2015: 3-4). An example of the latter is given in (10).

(10) Ganteng sih, ganteng tapi jahat banget.

handsome PART handsome but nasty very

'Sure, he's handsome but he's [also] a nasty bit of work.'

In written texts, the particle sih mostly occurs in questions as a rhetorical marker, and no significant differences in the meaning or position of the particle were revealed.

\section{$3.4 k o k$}

In the case of kok, both Sneddon (2006:123) and Johns (1993: 21) agree that this particle occurs in questions expressing surprise, suggesting 'how come' as an English equivalent. In statements, kok serves as an emphatic particle which could simply be rendered as 'you know'. In questions, it mostly occurs in the initial position, while in statements it usually takes the final position. For this particle, the dictionary entries are relatively consistent in their definitions. The 
KBBI generally sees kok as an emphatic particle in statements and, in questions, as an approximate equivalent of the question word 'why'. KD essentially echoes this definition, suggesting that the particle kok might be used when the speaker is surprised or angry. KII's definition concisely summarizes what Johns (1993: 21) has written on the topic. What is important to note here is that the KII entry underlines the fact kok very often denies what the interlocutor has said. Similarly, Johns (1993: 21) argues that it could also be used to mark a contradiction or rebuttal of what someone has said. Only the entry in KL seems to be inaccurate. The authors suggest that 'though', 'well', or 'dear me' could serve as appropriate English equivalents of the particle kok. The previous studies and the language material analysed in this paper do not support that argument.

In questions, the particle can occur at the beginning or at the end of a clause, and always conveys the meaning of surprise or even shock, as in (11).

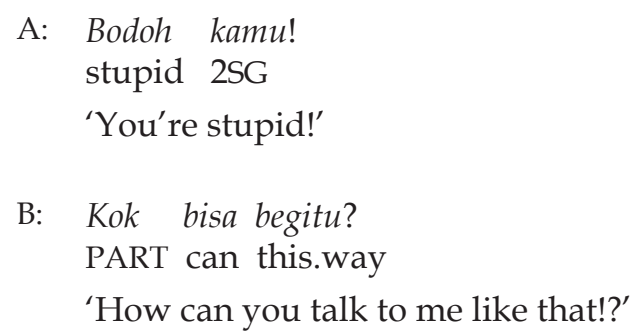

In most cases, the particle gives us a sense of the speaker's surprise. Sometimes it can also carry a shade of annoyance, as in (12).

(12) Ada disitu kok, deskripsi-nya.

there.is in there PART description

'It is all there, [look] in the description!'

In (12), the speaker seems to have expected the addressee to have read the description and is surprised that they are still asking questions about something which was supposed to be clear.

In written texts, the particle kok occurs most frequently in questions. It rarely takes strictly initial position, but is rather a part of fixed tags, such as kok bisa? ('how come?', 'how is that possible?') or kenapa kok? ('why?', 'why is that so?'). In statements, this particle seems to contradict the facts known or believed by the readers, sometimes carrying a meaning along the lines of "you think that X? No, we're going to show you that it's not!", as in (13).
Balkon rumah-mu
sempit? Bukan masalah kok! balcony house-2SG.POSS narrow not problem PART 'Is your balcony narrow? That's not a problem!' 


\section{5 tho}

The particle tho (occasionally also spelled loh, lo, or tha), however common, is the least well described in lexicographic works. Both definitions in KBBI and $\mathrm{KD}$ are very similar and suggest that the particle tho is used to express the speaker's surprise. The definitions of KII and KL, on the other hand, treat the particle mostly as an exclamation, suggesting 'hey!' or 'look!' as appropriate equivalents. An important fact is that tho is the only particle marked as Jv (Javanese) by one of the dictionaries (KII). In no other definitions can we find suggestions as to the origin of the particles. In the examples in this section taken from speech, the particle was transcribed as lho. In phrases collected from instant messaging, the original spelling was kept (lho, lha, or loh).

It is important to note that many works, particularly those analysing Javanese distinguish, the particle lha (only initial) from tho (other positions). ${ }^{4}$ In the collected material, the particle lha occurred in this form only in few cases in written texts. In speech, however, even when occurring in the initial position it was pronounced as $/ \mathrm{l} / \mathrm{s}$ and is therefore analysed as an equivalent of tho. Since this article is primarily concerned with CI, I have decided to not make a distinction between tha and tho here.

At the beginning of a clause, the particle tho expresses the speaker's surprise (Johns 1993: 80; Sneddon 2006: 123; Miyake 2015: 5), as can be seen in (14).

\section{(14) Lho! ada flash! \\ PART there.is flash \\ 'Oh [I didn't know] the flash was on!'}

Miyake (2015: 9) observes that in initial position, tho could be contrasted with particle kok, however tho is more emphatic. As observed in (15) lho has an additional function of introducing contrasting information. In (15) A is trying to convince $B$ that he was wrong and emphasizes that the previous statement was true.
A: Gak bisa mas, aku baru sampai di Jakarta. no can older.brother 1SG new arrive in PN 'I can't, I have just arrived in Jakarta.'
B: Kamu bohong lagi!
2SG lie again
'There you going, lying again!'

\footnotetext{
${ }^{4}$ Consider, for example, Bambang Kaswanti Purwo (1976) and Soepomo Poedjosoedarmo (1982). However, this distinction is not made in E.C. Horne (1961).
} 
A: Lha beneran, mas!
PART true older.brother

'No! I'm really telling you the truth!'

Miyake (2015: 5) observes the role of tho in introducing new information. In (16) however, we observe a reaction to new information expressed by tho. The interlocutors were discussing outdated teaching methods used in the classroom. When informed about the teachers' age, the speaker reacted.

(16) Lha, kalau guru-nya sudah tua pasti begitu.

PART if teacher already old sure that.way

'Well, if the teachers are on the old side, that's the way it's going to be.'

In final position, the particle tho commonly occurs in imperatives, often with a sense of warning (see Miyake 2015: 6), as in (17).

Jangan ke sana, ada banyak motor, tho! do.not to there there.is much motorbike PART

'Don't go there! There are a lot of motorbikes!'

In other instances, the particle tho in final positions serves emphatic purposes, frequently occurring in exclamations. One interesting instance was found in which the particle was used to emphasize the right information. In (18), A initially gave wrong directions (barat 'west'), later correcting himself by adding tho to stress that the second information was the correct one. It is worth mentioning here that in CI, particularly in so-called colloquial Jakartan Indonesian, there is a specific self-correcting particle ding (with a variant deng), ${ }^{5}$ which, however, has not been found in the material collected for this study.

$$
\begin{aligned}
& \text { A: Di sebelah barat masjid. } \\
& \text { in part west mosque } \\
& \text { '[It's] to the west of the mosque.' }
\end{aligned}
$$

B: Barat?

west

'[To the] west?'

A: Di sebelah utara, lho.

in part north PART

'[No, actually] to the north.'

In the written texts analysed here, the particle lho occurs in final position, with only one exception observed (20). Yet, in this instance, lho separates the topic of the sentence from its comment. Most occurrences of this particle have

${ }^{5}$ See D. Gil and U. Tadmor (2007). 
been observed in the titles of popular articles. Given the style of these articles and their character, tho serves as an additional emphasis in order to attract the readers' attention.

Ini sangat pas untuk kamu, karena sepertinya akan datang
this very fit for 2SG because it.seems FUT coz
seseorang yang kamu nantikan selama ini lho!
someone which 2SG wait until this PART

'It's [a] very good [prediction] for you, as it seems that someone you've been waiting for will [finally] come.'

In (19) we observe the typical emphatic meaning of the particle with an additional shade along the lines of "you will see that this is going to be the case!".

As mentioned above, (20) is the only instance of particle tho in a non-final position. In this example, the particle tho separates the topic from the comment and puts emphasis on a described character, who is supposed to be known to the readers. In this example, the combination itu lho (literally: that PART) seems to carry the meaning of "you know, that one"; "you know whom I'm talking about", et cetera. This example illustrates the typical conversational usage of the particle - the title of the article has features of a spontaneous phrase which might be found in a dialogue ("You remember him? It was that guy ...").

(20) Kamu masih ingat serial kartun Marsupilami? Itu tho si 2SG still remember series cartoon PM that PART CLASS

ekor panjang nan serba guna dengan kulit warna kuning. tail long which everything use with skin colour yellow

'Do you still remember cartoon series Marsupilami? That's that yellow guy with long, multi-purpose tail.'

In the texts analysed, tho functions mostly as an emphasizer. Only a few instances of tho as a particle expressing surprise have been noted. They have been found in articles in the form of a collection of photos/memes with comments on them. They are also quite common in articles which are structured like lists ("listicles").

\subsection{THE MEANINGS OF THE PARTICLES}

Based on the material gathered for this study, we can see that the particles do not easily fall into neat categories, largely because many functions of the described elements overlap. We can roughly divide the studied particles (dong, kok, sih, and tho) into two groups: "emphasizers" and "particles expressing surprise" (Table 2). 


\begin{tabular}{|l|l|}
\hline Emphasis & Expression of surprise \\
\hline kok in final position in statements & kok in final position in statements \\
\hline dong in statements and imperatives & kok in questions \\
\hline sih in statements & sih in questions \\
\hline lho in final position & $l h o+k o k$ \\
\hline lho in initial position & \\
\hline
\end{tabular}

Table 2. Functions of the particles.

By "emphasizer", I mean particles which carry a meaning similar to "It is certainly $X^{\prime \prime}$ or "You will see that it is $X^{\prime}$. . The particles expressing surprise convey meanings along the lines of "I was sure that $X$ was the case but it is not" or "It is usually X, why is it Y now?". The peculiarities of each particle will be addressed in more detail later in this section.

As we can observe in Table 2, only the particle dong does not play any role in expressing surprise. The particle kok can serve both purposes when used in statements, depending on the context, yet only when used in questions, does it imply the speaker's surprise. The particle sih, in turn, does not yield a clear definition. Even though this particle might possibly express surprise, in most instances it is used with sense of irony or sarcasm. Therefore, we do not, in most cases, speak of genuine surprise. Of the particles described, tho is most probably the easiest to define: it serves purely emphatic purposes, except when it co-occurs with the particle kok.

Another important role played by discourse particles is their function in introducing or commenting on new information. Particles which usually provide a comment on the new information are: sih (ironic attitude), kok (surprise), and tho (surprise, more emphatic). Particles playing a role in introducing a new information are sih (contrasting) and tho (new message or reintroducing information). Based on the above findings, the particles could be paraphrased in the following way:

lho:

1. "How come [you say] Y!? I told you that [it is] X!"

2. "Oh! I had no idea that [it is] X!"

3. "Look, it is X!" [the addressee has no previous knowledge or presumption about what is going to happen] alternatively: "Look what I found!"

4. "No, $X$ is not always the case!"

5. "You know" [or: "You should remember" in: <phrase> + itu tho ('that, lho'; 'that's it')]

6. "Don't/do that because X" [X usually not expressed, exists in the mind of the speaker as their previous observation]

7. "What!?"; "How come!?" [expressing strong surprise]

8. "No way!" [indicating obstacle]

9. "That's what I think" or: "That's the way it is"

10. "X. Period!" [ending an argument; reinforcing an insult] 
sih:

1. "Oh! This is so X!" [X usually expressed by an adjective]

2. "It is X, don't you think?" [expressed as a tag nggak sih? - 'isn't it?']

3. "Do you think I am going to believe that?" [idiomatic masa sih? which could be rendered as 'really?' or 'seriously?']

4. "What/Who could that be?" [with question words apa sih? siapa sih? - 'what sih? who sih?']

5. "But what exactly!?"

6. "What on earth!?"

7. "It was supposed to be $\mathrm{X}$, why is it $Y$ ?" [often implying: "what have you done?"]

8. "Also true, but there's nothing you can do about it"

9. "Yes, that's true, you're right" [very often as iya, juga sih-literally: 'yes, also sih']

10. "It is $X<$ hesitation $>$ oh yes, definitely $X \operatorname{sih}^{\prime}$ [often followed by further explanations]

11. "<question> I know I've already asked, remind me again please" or "What was that, again?"

12. "It is $X$, indeed, but $Y^{\prime \prime}$ [in idiomatic "<adjective> sih <adjective>, tapi ('but') $<$ another adjective $\left.{ }^{\prime \prime}\right]$

\section{kok:}

1. "It is usually $X$, why is it $Y$ now?"

2. "How come! It is impossible that $X "$

3. "Wow, this thing is quite/too X!"

4. "It is X, why would you think otherwise?"

5. "It is $X$, didn't you see?"

6. "It is $X$, you see, I wish/would expect it was $Y$ "

7. "Wow! X, I thought it can't be X"

8. "It's/here's X, didn't you see?"

9. "No, it is not what you think, it should be this way"

10 "I thought it was going to work but it actually doesn' $t$ "

\section{dong:}

1. "Obviously it is X"

2. "Come on, do it!" [in imperatives, giving a sense of encouragement, or as a dare]

3. "Please, just do it"

4. "Do it! You should have already done it!"

5. "It is X, like you didn't know"

6. "Don't you think it's X?"

7. "I know that you know!"

8. "Don't you agree?" [with a presumption that the addressee will express an agreement]

9. "It's not what you think, it's actually X"

10. "Is it X?"

11. "Of course it is X!" [implying: "why would you expect otherwise?"]

12. "Look, it is $\mathrm{X}$, don't you think!" 


\subsection{Collocations}

In the material studied I have also analysed the most common particle collocations occurring on the Brilio.net website. Quite surprisingly, very few fixed expressions showed up. In most instances the collocates were found between clauses. Therefore, not all results can be considered valid collocates. Such instances have been ignored in the description below.

Most of the observed collocations occurred between a particle and (in order of frequency):

a) another particle;

b) a preposition;

c) a modal verb;

d) another discourse particle.

An exception has been observed in case of particle tho, which collocates readily with non-modal verbs, common nouns, and adjectives.

The particle sih most frequently co-occurs with words such as tapi ('but'), nggak ('no'), gini ('like this/this way'), which reveals its role in contrasting information. For the particle kok, the most common collocate was the word bisa ('can'), forming an idiomatic phrase kok bisa? ('how is that possible?', 'how come?', 'how dare you?'). Other common collocations include nggak kok ('kok no!') and kok begini/begitu ('like this/that kok!'), which convey a nuance of surprise. The particle dong collocated with some common verbs, as it is frequently used in combination with imperatives. The most common collocate observed was kamu dong ('you dong') which could be translated as 'it's you, you're the one (not anybody else)!'. Among other combinations, no other phrases which could be considered fixed expressions were found. Similarly, in case of the particle tho, establishing any particular rule for collocation is difficult if not impossible. As mentioned above, the particle expresses surprise (more emphatically than the particle kok) and plays an important role in introducing new information.

In the examples discussed earlier, it has been observed that in most instances, the particle tho occurs in phrase-final position, so that no idiomatic expressions showed up. The collocates are mostly nouns, adjectives, and nonmodal verbs, for example: dunia ('the world'), bahagia ('happy'), luas ('wide'), coba ('to try'), asli ('original'), ternyata ('apparently'), et cetera.

\section{CONCLUSION}

This study has taken a closer look at discourse particles used in contemporary Colloquial Indonesian and their function in both spoken and written environments, explaining their functions and illustrating them with examples. It is important to repeat that the academic concept of "discourse particles" can still be considered somewhat fuzzy (see Jucker and Ziv 1998: 2). Therefore, I found it essential to construct a specific definition for the purpose of this study.

A vital part of the present analysis was to cross-examine the particles as used in speech with dictionary entries and the findings of other researchers. The discrepancies revealed between the dictionary definitions (especially 
KBBI) and the research material were not strikingly deep, nonetheless a revision of the entries is needed, as the major part of the definitions can be potentially misleading. The findings in Section 3 are in line with current research on the usage of Indonesian discourse particles, allowing few novel insights about the nature of the particles to be obtained. The most accurate descriptions of the particles have been given by Johns (1993), Miyake (2015), and Wouk $(1989,1999 a, 1999 b)$. However, the particles discussed by Wouk, $y a$ and kan, were not described in the present study.

Even though the Colloquial Indonesian particles have been described extensively, very little attention has been paid to these speech elements occurring in written text. The analysis undertaken here shows that there are not too many differences between the functions of the particles in spoken and written language. All the particles analysed in this paper were found in the example sentences used for the present analysis, and all of their functions were also revealed in the written texts without differences in meaning. Understandably, in the written texts we can readily extract collocations and fixed expressions, which appear more frequently. As I have shown, the character of the articles analysed in this study triggers certain types of expressions. Discourse particles are especially common in clickbait titles, which are almost always questions, imperatives, or very emphatic statements, as their main purpose is to attract the readers' attention.

It is also important to underline that the relationship between the writer and the reader, their roles, and the amount of common knowledge they share are not as easily discernible as in face-to-face communication. This shared knowledge is particularly important in the study of the particles' functions, because, as stated earlier, they provide a sort of situational commentary on the ongoing discourse. Nonetheless, the articles found at Brilio.net, besides being subdivided into thematic categories (which immediately give us hints about their contents), are copiously illustrated with photographs to which the texts of the articles often refer. Therefore, the visual elements play an important role in building the common ground (supported by the usage of informal style) between the author and the reader, which becomes a basis for a kind of a dialogue between the two. This puts the style of the material closer to spoken conversation. Unlike news articles, the material analysed features overt expressions; the authors explicitly share their evaluation of the described reality by means of direct, colloquial language, while making abundant use of discourse particles.

This study has shown that the particles discussed do not change the meaning of a given utterance, but rather imbue them with a certain flavour, making them more expressive and natural. Therefore, it is understandable that the particles prevail in the language of advertisements and commercials, as well as the language of longer texts. One conclusion is certain, we are going to observe an increase in the usage of Indonesian discourse particles, as it dovetails with the extensive use of colloquialisms nowadays. 


\section{AbBREVIATIONS}

$\begin{array}{ll}\text { 1SG } & \text { first person singular } \\ \text { 2SG } & \text { second person singular } \\ \text { CI } & \text { Colloquial Indonesian } \\ \text { CLASS } & \text { classifier } \\ \text { JV } & \text { Javanese } \\ \text { FUT } & \text { future tense marker } \\ \text { KBBI } & \text { Kamus Besar Bahasa Indonesia } \\ \text { KD } & \text { Kamus Dewan } \\ \text { KII } & \text { Kamus Inggris-Indonesia } \\ \text { KL } & \text { Kamus Lengkap } \\ \text { PART } & \text { particle } \\ \text { POSS } & \text { possessive } \\ \text { PN } & \text { proper name }\end{array}$

\section{REFERENCES}

Abdul Chaer and Augustina Leonie. 2004. Sosiolinguistik perkenalan awal. Jakarta: Rineka Cipta.

Ariel, Mira. 1998. "Discourse markers and form-function correlations", in: Andreas H. Jucker and Yael Ziv (eds), Discourse markers; Descriptions and theory, pp. 223-260. Amsterdam: John Benjamins. [Pragmatics and beyond new series 57.]

Badan Bahasa. 2016. Kamus Besar Bahasa Indonesia. [Available from: www. kbbi.kemdikbud.go.id/; accessed on 26-1-2019.]

Badudu, J.S., Lesmanesya, Livian Lubis, and Muchtar. 1984. Morfologi bahasa Indonesia (lisan). Jakarta: Pusat Pembinaan dan Pengembangan Bahasa, Departemen Pendidikan dan Kebudayaan.

Bambang Kaswanti Purwo. 1976. Presupposition in the Javanese particles "Ihotha-kok-rak-mbok-ta-ki-je"; A semantic and syntactic study. PhD thesis, Institut Keguruan dan Ilmu Pendidikan Malang.

Chambert-Loir, Henri. 1983. Citra masyarakat Indonesia. Jakarta: Sinar Harapan.

Demidjuk, Ljudmila, Ahmad Sujai, Jenni M.T. Harjatno, and Vladimir V. Sikorsky (eds). 2013. Učebnik indonezijskogo jazyka [Manual of Indonesian language]. Moscow: Moscow University Press.

Echols, John M. and Hasan Shadily. 2014. Kamus Inggris-Indonesia. Jakarta: Gramedia Pustaka Utama.

Englebretson, Robert. 2003. Searching for structure; The problem of complementation in colloquial Indonesian conversation. Amsterdam: John Benjamins.

Ewing, Michael C. 2005. “Colloquial Indonesian”, in: K. Alexander Adelaar and Nikolaus P. Himmelmann (eds), The Austronesian languages of Asia and Madagascar, pp: 227-258. London / New York, NY: Routledge.

Gil, D. and U. Tadmor. 2007. "The MPI-EVA Jakarta Child Language Database". [A joint project of the Department of Linguistics, Max Planck Institute for Evolutionary Anthropology and the Center for Language and Culture Studies, Atma Jaya Catholic University.] 
Grijns, C.D. 1991. Jakarta Malay; A multidimensional approach to spatial variation. Leiden: KITLV Press.

Hoogervorst, Tom G. 2018. "Utterance-final particles in Klang Valley Malay", Wacana, Journal of the Humanities of Indonesia Vol. 19 No. 2: 291-326.

Horne, E.C. 1961. Beginning Javanese. New Haven, CT: Yale University Press. Johns, Yohanni. 1993. Bahasa Indonesia; Langkah baru, Book 3. Canberra: Periplus Editions.

Jucker, Andreas H. and Yael Ziv (eds). 1998. Discourse markers; Descriptions and theory. Amsterdam: John Benjamins.

Maschler, Yael. 1998. "Rotsè lishmoa kéta? 'wanna hear something weird/funny [lit. 'a segment']?'; The discourse markers segmenting Israeli Hebrew talk-in-interaction", in: Andreas H. Jucker and Yael Ziv (eds), Discourse markers; Descriptions and theory, pp. 13-159. Amsterdam: John Benjamins.

Mintz, Malcolm Warren. 1994. A student's grammar of Malay and Indonesian. Singapore: EPB.

Miyake, Y. 2015. "Pragmatic particles and information structure in colloquial Indonesian dialogue", in: Proceedings of the second international workshop on information structure of Austronesian languages, pp. 103-114. Tokyo: Research Institute for Languages and Cultures of Asia and Africa (ILCAA), Tokyo University of Foreign Studies.

Muhadjir. 1981. Morphology of Jakarta dialect; Affixation and reduplication. Jakarta: Badan Penyelenggara Seri NUSA, Universitas Atma Jaya.

Noresah bt. Baharom, Hajah. 2007. Kamus Dewan [Dictionary of the Language Bureau]. Fourth edition. Kuala Lumpur: Dewan Bahasa dan Pustaka.

Nyan, Thanh. 2016. Context construction as mediated by discourse markers; An adaptive approach. Leiden: Brill.

Poedjosoedarmo, Soepomo. 1982. Javanese influence on Indonesian. Canberra: Department of Linguistics, Research School of Pacific Studies, The Australian National University.

Rahardi, R. Kunjana. 2001. Sosiolinguistik, kode dan alih kode. Yogyakarta: Pustaka Pelajar.

Rahayu, Siti Perdi. 1999. "Slang dalam bahasa Jawa; Analisis kasus di Malioboro Yogyakarta". MA thesis, Universitas Gadjah Mada, Yogyakarta.

Sneddon, James Neil. 2006. Colloquial Jakartan Indonesian. Canberra: Research School of Pacific and Asian Studies, The Australian National University. [Pacific Linguistics 581.]

Solikhan, Umar. 2006. Bahasa gaul; Sebuah slang dalam bahasa Indonesia. Semarang: Balai Bahasa.

Stede, Manfred and Birte Schmitz. 2000. “Discourse particles and discourse functions", Machine translation 15(1-2): 125-147.

Suwojo Wojowasito and Tito W. Wasito. 2007. Kamus lengkap. Bandung: Hasta. Wouk, Fay. 1989. The impact of discourse on grammar; Verb morphology in spoken Jakarta Indonesian. PhD thesis, University of California, Los Angeles.

Wouk, Fay. 1998. "Solidarity in Indonesian conversation; The discourse marker 'kan'", Multilingua 17(4): 379-406. 
Wouk, Fay. 1999a. "Gender and the use of pragmatic particles in Indonesian", Journal of Sociolinguistics 3(2): 194-219.

Wouk, Fay. 1999b. "Dialect contact and koineization in Jakarta, Indonesia", Language Sciences 21: 61-86.

Wouk, Fay. 2001. “Solidarity in Indonesian conversation; The discourse marker 'ya'", Journal of Pragmatics 33(2): 171-191.

Yuniar, Dientha. 2013. "'Ya' as discourse marker; Indonesian stand-up comedy strategy in producing laughter", International Journal of Applied Linguistics and English Literature 2(6): 103-110. 